\title{
Bark Characterization of Tachigali guianensis and Tachigali glauca from the Amazon under a Valorization Perspective
}

\author{
Graciene S. Mota, ${ }^{\mathrm{a}, *}$ Caroline J. Sartori, ${ }^{\mathrm{b}}$ Alessandra O. Ribeiro, ${ }^{\mathrm{a}}$ Teresa Quilhó, ${ }^{\mathrm{c}}$ \\ Isabel Miranda, ${ }^{\mathrm{c}}$ Gracialda C. Ferreira, ${ }^{\mathrm{d}}$ Fábio A. Mori, ${ }^{\mathrm{a}}$ and Helena Pereira ${ }^{\mathrm{c}}$ \\ Barks of Tachigali guianensis and Tachigali glauca, from the Brazilian \\ Amazon rainforest, were studied regarding anatomy and chemical \\ composition. The barks were similar, with a narrow rhytidome, a ring of \\ sclerified cells below the periderm, a widely dilated and sclerified \\ nonconducting phloem, septate crystal strands, and extensive phenolic \\ deposits in cells. Differences between the species were mainly in the \\ sclerenchyma. Proportions of cell types in the T. guianensis and T. glauca \\ barks were, respectively: $27.8 \%$ and $28.3 \%$ axial parenchyma, $15.6 \%$ and \\ $15.1 \%$ sieve tube elements, $11.6 \%$ and $13.4 \%$ radial parenchyma, $15.6 \%$ \\ and $8.7 \%$ sclereids, and $30.5 \%$ and $34.5 \%$ fibers. Chemical analysis \\ showed that the T. guianensis and $T$. glauca barks included, respectively: \\ $18.0 \%$ and $15.3 \%$ extractives, $1.8 \%$ and $1.0 \%$ suberin, $26.8 \%$ and $27.9 \%$ \\ lignin, and $3.5 \%$ and $4.5 \%$ ash. The predominant polysaccharides were \\ glucose $(72.8 \%$ and $82.8 \%$ of total neutral sugars) and xylose $(17.9 \%$ and \\ $11.6 \%$ ). Ethanol-water extracts were high in phenolics (total phenolics of \\ $441.0 \mathrm{mg}$ gallic acid equivalents (GAE) / g extract and $641.7 \mathrm{mg}$ GAE / g \\ extract), with moderate antioxidant activities ( $/ C_{50}$ values of $7.3 \mu \mathrm{g}$ extract \\ / $\mathrm{mL}$ and $5.6 \mu \mathrm{g}$ extract / $\mathrm{mL}$ ). Tachigali guianensis bark and, particularly, \\ T. glauca bark may be sources of phenolic compounds.
}

Keywords: Tachigali guianensis; Tachigali glauca; Bark; Anatomy; Chemical composition; Extractives

Contact information: a: Departamento de Ciências Florestais, Universidade Federal de Lavras, Lavras, Minas Gerais, Brazil; b: Instituto Federal de Minas Gerais, São João Evangelista, Minas Gerais, Brazil; c: Centro de Estudos Florestais, Instituto Superior de Agronomia, Universidade de Lisboa, Tapada da Ajuda, 1349-017 Lisboa, Portugal; d: Universidade Federal Rural da Amazônia, Instituto de Ciências Florestais, 66053100 - Belém, PA, Brazil; *Corresponding author: imiranda@isa.ulisboa.pt

\section{INTRODUCTION}

Tree barks are a potential feedstock for the production of added-value products, including chemical compounds with interesting reactive functionalities and biochemical properties, such as antioxidant and biological activities, which may be applied in several industrial sectors (Jansone et al. 2017). Barks are increasingly viewed as resources for biorefineries given their wide availability, often as residual streams resulting from industrial processing, and their rich chemical and structural diversity.

The number of studies that characterize barks of different species is steadily increasing. These studies focus on the structural, chemical, and energy features of barks, as well as on several processing routes for their valorization. Anatomical and chemical characterization has been presented for barks of temperate species, such as Quercus cerris (Şen et al. 2010, 2011), Betula pendula (Miranda et al. 2013; Ferreira et al. 2017), Eucalyptus globulus (Neiva et al. 2018a; Gominho et al. 2020), Eucalyptus spp. (Ferreira 
et al. 2018; Lima et al. 2018), Picea abies (Neiva et al. 2018b), and Pseudotsuga menziesii (Ferreira et al. 2015; Cardoso et al. 2018), and also barks of tropical species, including Eucalyptus urophylla (Sartori et al. 2016), Albizia niopoides (Carmo et al. 2016a), Copaifera langsdorffii (Carmo et al. 2016b), Goupia glabra (Carmo et al. 2016c), Anadenanthera peregrina, and A. colubrina (Mota et al. 2017). Natural products are generally considered as attractive added value compounds based on their broad spectrum of bioactivity, and their extraction has been considered for bark of different species (Şen et al. 2011; Vázquez et al. 2012; Tanase et al. 2019; Araujo et al. 2020) and as bioindicators of environmental pollution (Xu et al. 2018). Some barks also have proven efficient for the production of medium density particleboards (MDP) (Soratto et al. 2013) and pulp (Miranda et al. 2012; Neiva et al. 2016). Some species have a high proportion of cork in their bark and may therefore be a source of this valuable industrial raw material (Leite and Pereira 2017).

The use of barks in added-value products, their selection, and the choice of processing routes require a detailed characterization of the specific bark. An important aspect underlying a bark's potential use is its availability, considered in terms of amount, location, and seasonality. Bark is one of the most abundant biomass types, with a broad geographical distribution and representing $\mathrm{ca} .9 \%$ to $15 \%$ of the volume of tree stems and branches (Harkin and Rowe 1971), and is often unaccounted for or left as an underutilized biomass fraction when integrated in overall use of forest-based resources. Valorization of the bark may therefore contribute to sustainable forest use and increase revenues at the local level. This is particularly true in fragile environmental or socio-economic contexts such as the Amazon region.

In Brazil, the Amazon is the largest biome with distinct ecosystems and has over 2500 tree species (Ministry of the Environment 2019). Among them, the species from the genus Tachigali Aubl., from the family Leguminosae (Fabaceae) and subfamily Caesalpinioideae, are economically important as a timber source for construction, bridges, fences, furniture, and landscaping and restoration (Lorenzi 1992, 1998).

The Tachigali species, known in Brazil as táxi, are under legal protection and regulation as producers of quality timber (madeira de lei) (Camargos et al. 2001). The genus includes 60 to 70 species and is Neotropical, with a distribution from Costa Rica to the south of Brazil and Paraguay (van der Werff 2008; Macedo et al. 2014), but it is more represented in the Atlantic Forest (Mata Atlântica) of the south of Brazil and in the north of South America (van der Werff and Zamora V. 2010). The genus Tachigali Aubl. now includes, after several taxonomic studies, the formerly distinct genus Sclerolobium Vogel (Graham and Barker 1981; Haston et al. 2005; Lewis et al. 2005; Silva and Lima 2007; van der Werff 2008).

Tachigali guianensis and Tachigali glauca are easily identified by the morphologies of their branches, leaves, and flowers (van der Werff 2008). Tachigali guianensis has a broad distribution in Brazil, Guyana, French Guiana, Suriname, Venezuela, Colombia, Peru, and Bolivia. The trees may attain a height of $30 \mathrm{~m}$ and are cut in the forest for timber and occasionally for natural dyes (Huamantupa-Chuquimaco et al. 2016). Tachigali glauca has an important contribution to the formation of the Amazonian forest, especially in dry land forests, and is reported across the Brazilian Amazon (Pará, Amapá, and Roraima) and in French Guiana (van der Werff 2008). Tachigali glauca trees may reach $40 \mathrm{~m}$ in height under natural conditions (Reis et al. 2015). They have been little exploited apart from charcoal production, but the timber quality associated with their potential use in forest restoration makes it an attractive species for the timber industry 
(Soares et al. 2019). Both species are intolerant of shade and require high light conditions, and they are considered fast growth species (Gama 2002; Ortiz et al. 2006; HuamantupaChuquimaco et al. 2016).

Studies on Tachigali species are scarce. Wood anatomy has been studied for species of Sclerolobium and species of Tachigali (Loureiro et al. 1983; Pernía and Melandri 2006; Gasson et al. 2003; Reis et al. 2011; Macedo et al. 2014), S. chrysophyllum and T. paniculata (Aparecido et al. 2019), and T. glauca (=T. myrmecophila) (Fedalto et al. 1989). Some wood physical, chemical, and mechanical properties have been studied for $T$. vulgaris (Orellana et al. 2018; Tonini et al. 2018; dos Santos Silva et al. 2019), S. paniculatum (do Vale et al. 2010), and T. glauca (Silva 2018).

To the authors' knowledge, the only studies on bark refer to T. paniculata Aubl. (Roth 1981), S. aureum, S. paniculatum var. rubiginosum, and S. paniculatum var. subvelutinum (Pereira 1990; Costa et al. 1997). In this work, the barks of T. guianensis and T. glauca from the Amazon were described for the first time in relation to their anatomical and chemical characteristics, including the compositions and antioxidant properties of their extracts in view of their potential valorization.

\section{EXPERIMENTAL}

\section{Sampling}

Bark samples were obtained from Tachigali guianensis and Tachigali glauca trees in two different locations in the natural Amazonian forest belonging to the Brazilian State of Pará. In both locations, the forest was heterogeneous with different species and uneven ages of trees. One site was located in the Abaetetuba municipality (Northeast mesoregion; $1^{\circ} 43^{\prime} 46^{\prime} \mathrm{S}, 48^{\circ} 52^{\prime} 27^{\prime}$ ' $\mathrm{W}$, altitude $16 \mathrm{~m}$; tropical humid climate, with an average annual temperature of $27^{\circ} \mathrm{C}$ and an annual rainfall of $2577 \mathrm{~mm}$ to $2900 \mathrm{~mm}$ ), and the other was located in Jacundá municipality (Southeast mesoregion; 4 $27^{\prime} 03$ ' S, 49 $06^{\circ}$ '59" W, altitude $96 \mathrm{~m}$; tropical humid climate, with an average annual temperature of $26^{\circ} \mathrm{C}$ and an annual rainfall of $2000 \mathrm{~mm}$ to $2400 \mathrm{~mm}$ ). The botanical material was deposited in the ESAL Herbarium of Federal University of Lavras. T. guianensis voucher numbers: 4175 (Abaetetuba municipality) and 4174 (Jacundá municipality). T. glauca voucher numbers: 4181 (Abaetetuba municipality) and 4180 (Jacundá municipality).

At each site, three trees of each species were randomly selected. The sampled $T$. guianensis trees had over-bark diameters at breast height in the range of $11 \mathrm{~cm}$ to $20 \mathrm{~cm}$ and heights in the range of $7 \mathrm{~m}$ to $16 \mathrm{~m}$. The sampled $T$. glauca trees had over-bark diameters at breast height in the range of $7 \mathrm{~cm}$ to $18 \mathrm{~cm}$ and heights in the range of $14 \mathrm{~m}$ to $18 \mathrm{~m}$. The ages of the trees varied between 27 years and 35 years. The bark samples were taken at $1.3 \mathrm{~m}$ of stem height.

\section{Anatomical Characterization}

Macroscopic observations were made on the cross-sections of samples after surface sanding using a microscope (Leica MZ6, Leica Microsystems, Wetzlar, Germany) and photographed with a digital Samsung 10-MP L201 camera (Samsung, Seoul, South Korea). For microscopic observation, the samples were impregnated with polyethylene glycol (PEG) 1500 and sectioned with a sliding microtome (Leica SM 2400, Leica Biosystems, Nussloch, Germany) to obtain $13-\mu \mathrm{m}$ to $15-\mu \mathrm{m}$ transversal, tangential, and radial sections (Barbosa et al. 2010). The sections were stained with chrysoidine / astra blue and mounted 
on Kaiser glycerin. After $24 \mathrm{~h}$, the slides were immersed in ethanol and butyl acetate (1:3) for $5 \mathrm{~min}$ and in butyl acetate for $3 \mathrm{~min}$ to remove the impregnation material and mounted in Entellan (Merck, Darmstadt, Germany).

Samples were also taken from the cambium to the outside, macerated in a solution of $30 \% \mathrm{H}_{2} \mathrm{O}_{2}$ and $\mathrm{CH}_{3} \mathrm{COOH}$ at $60{ }^{\circ} \mathrm{C}$ for $48 \mathrm{~h}$, and stained with astral blue and safranine. All measurements were made using a semi-automatic image analyzer (Leica Qwin V 3.5.0 software, Leica Microsystems, Wetzlar, Germany). The parameters measured and the number of measurements for each specimen were as follows: sieve tube element diameter (30 sieve tube elements measured in the transverse section); sieve tube element length (30 sieve tube elements); and fiber length, width, and cell wall thickness (30 fibers, measured in the macerated material).

The proportions of cell types in the phloem were determined using a 48-point grid on 3 areas/sample in the transverse sections, from cambium to periderm, and Leica Application Suite V 4.2 software (Leica Microsystems, Wetzlar, Germany). Sieve tubes were quantified only in the non-collapsed phloem. The microscopic observations were made with a Leica DMLA optical microscope (Leica Microsystems, Wetzlar, Germany), and the photomicrographs were taken with a Nikon FXA camera (Nikon Corporation, Tokyo, Japan). Terminology followed Angyalossy et al. (2016).

\section{Chemical Characterization}

The bark samples were air dried at ambient conditions. The bark samples were ground using a cutting mill (Retsch SM 2000, Haan, Germany) with an output sieve of 1 $\mathrm{mm} \times 1 \mathrm{~mm}$. The ground material was sieved in a vibratory apparatus, and the 40 -mesh to 60-mesh fraction was used for chemical analysis. Bark composite samples of the three trees per species were made and carefully homogenized before analysis.

The summative chemical analyses of the barks were made according to Technical Association of the Pulp and Paper Industry (TAPPI) standard methods. The ash content was determined by weighing the residue after complete incineration of a 2.0-g sample in a muffle furnace at $525{ }^{\circ} \mathrm{C}$ overnight (TAPPI T 211 om-02 2002). Extractives were determined using extraction thimbles by successive Soxhlet extractions with dichloromethane $(6 \mathrm{~h})$, ethanol (16 h), and water (16 h) as mass losses of the oven-dried thimbles after each extraction.

Suberin content was determined in a 1.5-g sample of extractive-free material by methanolysis for depolymerization (Pereira 1988). The sample was refluxed with $100 \mathrm{~mL}$ of $3 \% \mathrm{NaOCH}_{3}$ solution in $\mathrm{CH}_{3} \mathrm{OH}$ for $3 \mathrm{~h}$, filtrated, and washed with methanol, and the filtrated residue was refluxed with $100 \mathrm{~mL}$ of $\mathrm{CH}_{3} \mathrm{OH}$ for $15 \mathrm{~min}$ and filtrated. The combined filtrates were acidified to $\mathrm{pH} 6$ with 2- $\mathrm{M} \mathrm{H}_{2} \mathrm{SO}_{4}$ and evaporated to dryness. The residue was suspended in $50 \mathrm{~mL}$ of water, and the alcoholysis products were recovered with dichloromethane in three successive extractions, each with $50 \mathrm{~mL}$ of dichloromethane. The combined extracts were dried over anhydrous $\mathrm{Na}_{2} \mathrm{SO}_{4}$, and the solvent evaporated to dryness. Suberin is a polyester macromolecule of glycerol esterified to long chain $\omega$ hydroxyacids, $\alpha, \omega$-diacids, and alkanoic acids, that is solubilised by cleavage of the ester bonds in the $\mathrm{NaOCH}_{3}$ catalysed methanolic solution (Pereira 2007). The suberin extracts, which include the fatty acids and fatty alcohol monomers of suberin, were quantified gravimetrically.

Klason lignin (TAPPI T 222 om-02 2002), acid-soluble lignin (TAPPI UM 250 om93 1993), and carbohydrate contents were determined using $0.35 \mathrm{~g}$ of extracted and desuberinised samples. Sulfuric acid $(72 \%, 3.0 \mathrm{~mL})$ was added to the sample, and the 
mixture was placed in a water bath at $30{ }^{\circ} \mathrm{C}$ for $1 \mathrm{~h}$, after which the sample was diluted to a concentration of $3 \% \mathrm{H}_{2} \mathrm{SO}_{4}$ and hydrolyzed for $1 \mathrm{~h}$ at $120{ }^{\circ} \mathrm{C}$. The sample was vacuumfiltered through a crucible and washed with boiling purified water. Klason lignin was determined as the mass of the solid residue after drying at $105{ }^{\circ} \mathrm{C}$, and acid-soluble lignin was determined for the filtrate by measuring the absorbance at $206 \mathrm{~nm}$ using a UV/VIS spectrophotometer. Klason lignin and acid-soluble lignin were reported as percentages of the original sample and combined to yield the total lignin content.

The polysaccharide composition was calculated based on the amount of neutral sugar monomers released by total hydrolysis as quantified by high-performance anionexchange chromatography (Dionex ICS-3000 system equipped with an electrochemical detector, Dionex, Sunnyvale, CA, USA). The separation was performed with Aminotrap plus CarboPac SA10 anion-exchange columns. The mobile phase was an aqueous 2-nM $\mathrm{NaOH}$ solution at a flow rate of $1.0 \mathrm{~mL} / \mathrm{min}$ at $25^{\circ} \mathrm{C}$.

All the experiments were performed in duplicate samples.

\section{Composition and Antioxidant Activity of Polar Extracts}

The phenolic compounds were extracted with a 50/50 ethanol/water mixture (v/v) for $60 \mathrm{~min}$ at $50{ }^{\circ} \mathrm{C}$ using an ultrasonic bath, and the obtained extracts were analyzed in relation to their total phenolic, flavonoid, and condensed tannin contents. Furthermore, their antioxidant activities were tested using the 2,2-diphenyl-1-picryhydrazyl (DPPH) method.

The total phenolic content was determined by the Folin-Ciocalteu assay (Singleton and Rossi 1965). In a test tube, $4 \mathrm{~mL}$ of the Folin-Ciocalteu $(1: 10, \mathrm{v} / \mathrm{v})$ reagent and $4 \mathrm{~mL}$ of $\mathrm{Na}_{2} \mathrm{CO}_{3}(7 \%, \mathrm{~m} / \mathrm{v})$ solution were added to $100 \mu \mathrm{L}$ of bark extracts. After $60 \mathrm{~min}$ of incubation in a thermostatic water-bath at $45{ }^{\circ} \mathrm{C}$, the absorbances of the resulting blue mixtures were recorded with a spectrophotometer (UV-160A Recording Spectrophotometer, Shimadzu, Kyoto, Japan) at $760 \mathrm{~nm}$ against a blank. Total phenolic content was determined as gallic acid equivalents (GAE) using the linear regression equation $(y=$ $\left.0.0076 x+0.0108, \mathrm{R}^{2}=0.9995\right)$ obtained from the standard curve of gallic acid $(5 \mathrm{mg} / \mathrm{mL}$ to $100 \mathrm{mg} / \mathrm{mL}$ ) and expressed as $\mathrm{mg}$ of GAE / $\mathrm{g}$ of the dry bark extract.

Flavonoid content was estimated according to the aluminium chloride colorimetric method (Zhishen et al. 1999). An aliquot $(1.0 \mathrm{~mL})$ of the extract was mixed with $4.0 \mathrm{~mL}$ of deionized water and with $0.3 \mathrm{~mL}$ of $\mathrm{NaNO}_{2}$ solution $(5 \%, \mathrm{~m} / \mathrm{v})$ and kept for $5 \mathrm{~min}$ in the dark. Then, $0.3 \mathrm{~mL}$ of $\mathrm{AlCl}_{3} \cdot 6 \mathrm{H}_{2} \mathrm{O}$ solution $(10 \%, \mathrm{~m} / \mathrm{v})$ was added to the mixture. After 5 min, $2.0 \mathrm{~mL}$ of $1-\mathrm{M} \mathrm{NaOH}$ solution and $2.4 \mathrm{~mL}$ of water were added sequentially and shaken. The absorbances were measured at $415 \mathrm{~nm}$. The flavonoid content was determined by interpolation on the calibration curve (Abs=0.0078 [Q]-0.0089, $\left.\mathrm{R}^{2}=0.999\right)$ constructed with catechin solutions ranging from $0 \mathrm{mg} / \mathrm{L}$ to $200 \mathrm{mg} / \mathrm{L}$. The results were expressed as mg of catechin equivalents (CE) / $\mathrm{g}$ of the dry bark extract.

Condensed tannins were estimated by the vanillin- $\mathrm{H}_{2} \mathrm{SO}_{4}$ method (Abdalla et al . 2014). An aliquot (1.0 mL) of the extract was added to $2.5 \mathrm{~mL}$ of vanillin solution $(1.0 \%$, $\mathrm{m} / \mathrm{v}$ in methanol) and $2.5 \mathrm{~mL}$ of sulfuric acid $(25 \%, \mathrm{v} / \mathrm{v}$ in methanol), and the volume of $10 \mathrm{~mL}$ was completed with methanol. The extract samples and blanks (with $1 \mathrm{~mL}$ of methanol) were incubated for $15 \mathrm{~min}$. Absorbances were recorded at $500 \mathrm{~nm}$, and results were expressed as $\mathrm{mg}$ of (+)-catechin equivalents (CE) / $100 \mathrm{~g}$ of the dry bark extract. The same procedure was followed for preparation of the catechin calibration plot from standards with concentrations ranging from $0.01 \mathrm{~g} / \mathrm{L}$ to $0.1 \mathrm{~g} / \mathrm{L}\left(y=0.0738 x+0.0054, \mathrm{R}^{2}\right.$ $=0.996)$. The results were expressed as $\mathrm{mg}$ of CE $/ \mathrm{g}$ of extract. 
The DPPH method was performed as described by Sharma and Bhat (2009), and the results were expressed in terms of the amount of extract required to reduce $50 \%$ of the DPPH concentration $\left(I C_{50}\right)$ and of Trolox equivalents (TEAC) on a dry extract base $(\mathrm{mg}$ Trolox / mg dry extract).

Different dilutions of the initial extract and of a stock Trolox solution $(0.2 \mathrm{mg} / \mathrm{mL})$ in methanol were prepared. An aliquot of $100 \mu \mathrm{L}$ of each methanolic solution of the extract and of Trolox was added to $3.9 \mathrm{~mL}$ of a DPPH methanolic solution $(24 \mu \mathrm{g} / \mathrm{mL})$. The blank sample consisted of $100 \mu \mathrm{L}$ of methanol added to $3.9 \mathrm{~mL}$ of DPPH solution. After a $30 \mathrm{~min}$ incubation period at room temperature in the dark, the absorbance was measured at 515 $\mathrm{nm}$. The DPPH radical scavenging activity was calculated as in Eq. 1,

$D P P H$ radical scavenging activity $(\%)=\left[\left(A b s_{0}-A b s_{1}\right) / A b s_{0}\right] \times 100$

where $A b s_{0}$ is the absorbance of the blank, and $A b s_{1}$ is the absorbance in the presence of the extract at different concentrations. The $I C_{50}$ inhibiting concentration, which represents the concentration of a sample necessary to sequester $50 \%$ of the DPPH radicals, was obtained by plotting the inhibition percentage against the extract concentration. The results were compared to standards (ascorbic acid, catechin, and gallic acid).

All the experiments were performed in duplicate samples.

\section{RESULTS AND DISCUSSION}

\section{Bark Structure and Anatomy}

The barks of $T$. guianensis and $T$. glauca were externally wrinkled due to the presence of lenticels and protuberances. The barks were dark grey or brown and thin, with average thicknesses of $3.45 \mathrm{~mm} \pm 2.10 \mathrm{~mm}$ and $2.31 \mathrm{~mm} \pm 0.10 \mathrm{~mm}$, respectively. A similar bark thickness was recorded by Roth (1981) for other Tachigali species (e.g., T. paniculatum) growing in tropical rainforests in Venezuela and is classified as very thin bark ( $1 \mathrm{~mm}$ to $3 \mathrm{~mm}$ ). The barks of both species included the rhytidome and phloem (Figs. 1, 2A, and 3A) and showed general anatomy features similar to barks of other Tachigali (Sclerolobium) species, such as T. paniculatum, S. paniculatum (Roth 1981), S. aureum, S. paniculatum var. rubiginosum, and $S$. paniculatum var. subvelutinum (Costa et al. 1997).
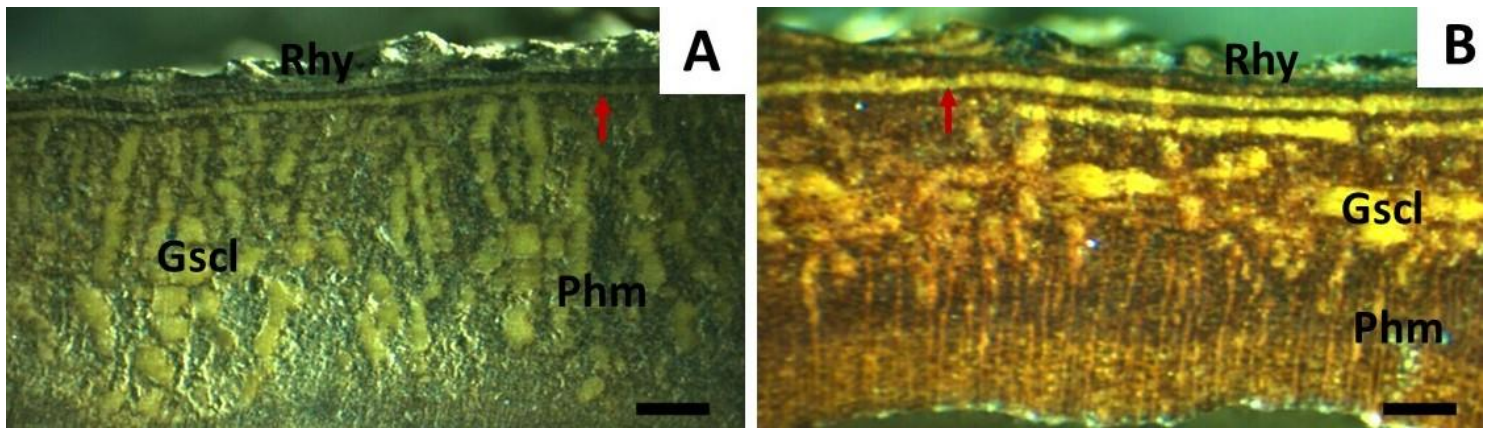

Fig. 1. Barks of (A) Tachigali guianensis and (B) Tachigali glauca observed under a binocular stereoscope (transverse section): rhytidome (Rhy), phloem (Phm) with groups of sclereids (Gscl), continuous ring of sclerified cells below the periderm (arrow). Scale bars: (A) $1 \mathrm{~mm}$ and (B) $1 \mathrm{~mm}$

The rhytidomes of $T$. guianensis and $T$. glauca were poorly developed, with mean thicknesses of $0.33 \mathrm{~mm} \pm 0.18 \mathrm{~mm}$ and $0.18 \mathrm{~mm} \pm 0.07 \mathrm{~mm}$, respectively, and generally 
included one periderm, with two periderms in only a few cases (Figs. 2A and 3A). An inconspicuous rhytidome was also observed in two species of Sclerolobium (Roth 1981). The lenticels were frequent and showed a stratified (heterogeneous) filling tissue, composed of alternating layers of loose, nonsuberized tissues and compact, suberized layers (Figs. 2A and 3A).
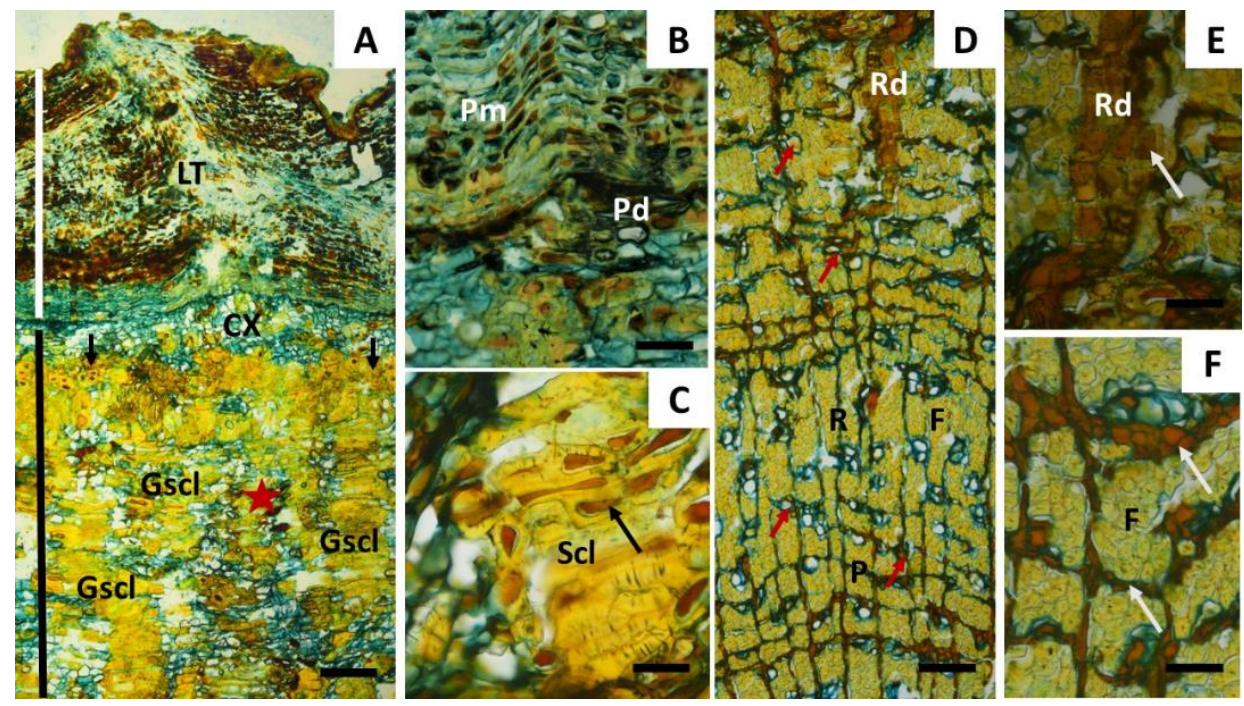

Fig. 2. Bark of Tachigali guianensis observed under optical microscope (transverse section): (A) rhytidome (white line) with lenticels (LT), portion of cortex (CX) and phloem (black line) with groups of sclerified cells (Gscl) in a large dilating zone (red star), and portion of the continuous ring of sclerified cells (arrows); (B) detailed portion of phellem (Pm) and the phelloderm (Pd); (C) sclereids (Scl) filled with phenolic compounds (black arrow); (D) secondary phloem with axial parenchyma $(P)$, fibers $(F)$, rays $(R)$, a dilated ray $(R d)$, and secretory cells (red arrows); (E) detail of a dilated ray with sclerified cells; and $(F)$ abundant phenolic compounds in the axial parenchyma cells (white arrows) and in the rays and fibers (F) (round to polygonal) in transverse outline. Scale bars: (A) $200 \mu \mathrm{m}$, (B and F) $40 \mu \mathrm{m}$, (C and E) $100 \mu \mathrm{m}$, and (D) $150 \mu \mathrm{m}$

The periderm, composed of phellem, phellogen, and phelloderm, developed in nearly continuous concentric layers. In both species, the phellem layer comprised a variable number of mainly thin-walled and somewhat rectangular cells in radially oriented rows in the transverse sections with cells evenly thick-walled and sclerified, sometimes with inclusions of presumably phenolic compounds (Figs. 2B and 3B). Phellem with phenolic compounds has been observed in other species, such as Erythroxylum tortuosum (Alonso and Machado 2008) and Quercus cerris var. cerris (Şen et al. 2011). In both species, the phelloderm was formed by one or three layers of cells, ranging from rectangular to round, with thin walls that occasionally may thicken and even be sclerified and filled with contents (Figs. 2B and 3B).

The two Tachigali species resemble one another in general anatomical features of the secondary phloem, despite some differences mainly related to the arrangement of the sclerenchyma tissues (fibers and sclereids). The dilatation phenomena is the way in which the bark is able to accommodate the radial growth of the tree by parenchyma cell division and cell expansion (Angyalossy et al. 2016). In this species, the dilatation growth was moderate mainly in the cortical cells of the cortex and occurred in both rays and axial parenchyma of the secondary phloem through tangential cell expansion and anticlinal cell division. (Figs. 2A and 3A). In the dilating zone of the outer portion of the phloem, a 
continuous ring of sclerified cells was observed in both species (Figs. 1A, 1B, 2A, and 3A), as groups of sclereids with phenolics (Figs. 2A, 2C, 3A, and 3C). The sclereids showed a radial arrangement in $T$. guianensis (Fig. 1A and 2A) and appeared in large irregular groups in T. glauca (Figs. 1B and 3A). Rings of sclerified cells occur in different species of Caesalpinioideae and Mimosaceae (Roth 1981; Carmo et al. 2016a; Mota et al. 2017).
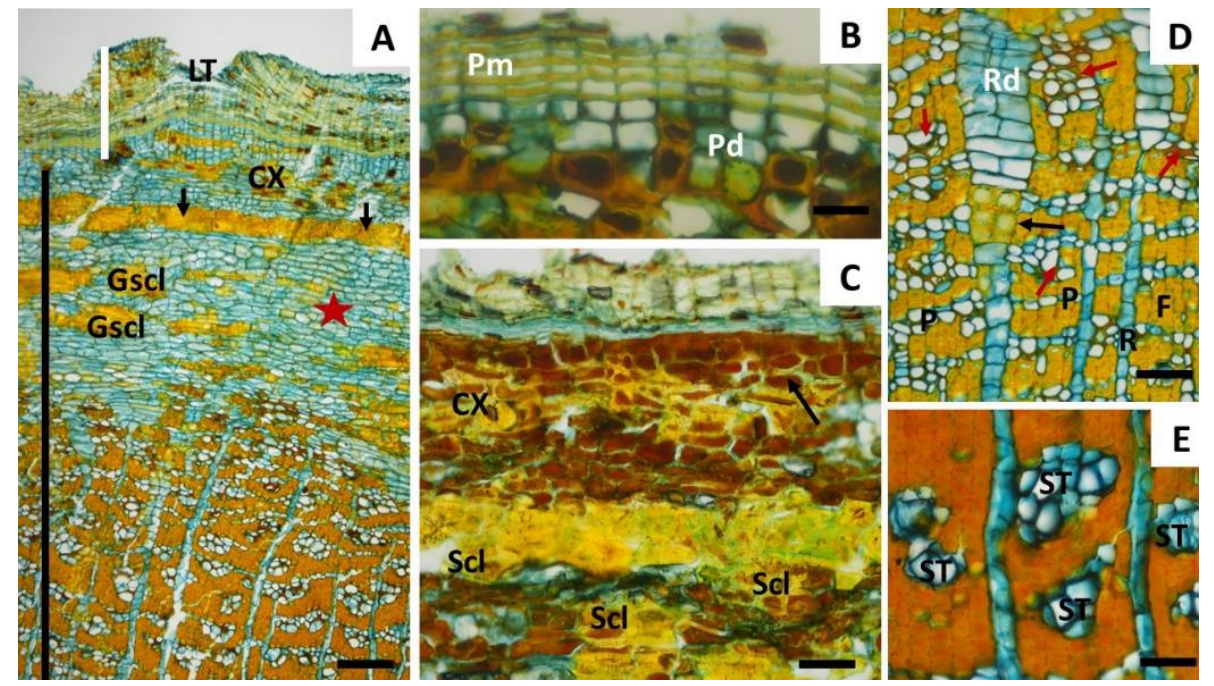

Fig. 3. Bark of Tachigali glauca observed under optical microscope (transverse section): (A) rhytidome (white line) with lenticels (LT), portion of cortex (CX) and phloem (black line) with groups of sclerified cells (Gscl) in a large dilating zone (red star), and portion of the continuous ring of sclerified cells (arrows); (B) detailed portion of phellem (Pm) and the phelloderm (Pd); (C) sclereids (Scl) and sclerified cells of the cortex (CX) filled with phenolic compounds (black arrow); (D) detail of a dilated ray (Rd) with sclerified cells (black arrow), axial parenchyma (P), fibers (F) with square shape in transverse outline, rays $(R)$, and secretory cells (red arrows); and (E) sieve tube elements (St). Scale bars: (A) $150 \mu \mathrm{m}$, (B and E) $40 \mu \mathrm{m}$, and (C and D) $100 \mu \mathrm{m}$

The phloem thicknesses were $2.32 \mathrm{~mm} \pm 0.98 \mathrm{~mm}$ and $1.59 \mathrm{~mm} \pm 0.38$ in $T$. guianensis and T. glauca, respectively, with a more or less gradual transition from conducting phloem to nonconducting phloem. In the conducting phloem, the sieve tube elements with their companion cells were well recognized by their diameter and oval-toround shape in the transverse section (Fig. 3E), isolated or in groups dispersed between axial parenchyma and fibers. The sieve plates were of scalariform type, composed with 8 to 23 elongate sieve areas in a ladder-like arrangement (Fig. 4B and 4D). The sieve tube elements occupied $15.5 \%$ and $15.0 \%$ of the conducting phloem in T. guianensis and $T$. glauca, respectively, with average lengths and tangential diameters, respectively, of 534.2 $\mu \mathrm{m} \pm 51.9 \mu \mathrm{m}$ and $30 \mu \mathrm{m} \pm 3.6 \mu \mathrm{m}$ in $T$. guianensis and $565.9 \mu \mathrm{m} \pm 58.8 \mu \mathrm{m}$ and $25.8 \mu \mathrm{m}$ $\pm 3.8 \mu \mathrm{m}$ in $T$. glauca. In the nonconducting phloem, the sieve tubes and their companion cells were obliterated and difficult to recognize.

The axial parenchyma represented $28.0 \%$ of the phloem in T. guianensis and $28.5 \%$ in $T$. glauca. The cells were rectangular to polygonal in the transverse outline with thin unlignified walls, arranged in thin tangential bands of one to three cells near the sieve tube elements (Figs. 2D, 2F, and 3D). In the nonconducting phloem, they proliferated and expanded, forming the large dilated zone.

The rays were non-storied, uniseriate (Fig. 4A and 4D), and homocellular, composed of procumbent cells (Fig. 4B and 4E). Similar rays are described for different species of Sclerolobium, such as S. aureum, S. paniculatum var. rubiginosum, and $S$. 
paniculatum var. subvelutinum (Costa et al. 1997). In T. guianensis and T. glauca, respectively, the rays occupied $11.5 \%$ and $13.5 \%$ of the secondary phloem, the numbers of rays per $\mathrm{mm}$ were $7.5 \pm 0.83$ and $6.0 \pm 0.95$, and the average ray heights were 7.5 cells \pm 1.1 cells and 9 cells \pm 0.9 cells and $33.6 \mu \mathrm{m} \pm 4.8 \mu \mathrm{m}$ and $16.3 \mu \mathrm{m} \pm 1.2 \mu \mathrm{m}$. The rays followed a more or less straight course in the conducting phloem, but they became rather irregular with moderate dilatation towards the periphery, due to tangential stretching and anticlinal cell divisions (Fig. 3D). Sclerification of radial parenchyma cells, often with brown contents, was observed in the enlarged rays in the beginning of the nonconducting phloem in both species (Figs. 2E and 3D). Radial parenchyma cells' sclerification has been reported in other genera, e.g., Quercus spp. (Şen et al. 2011; Quilhó et al. 2013).

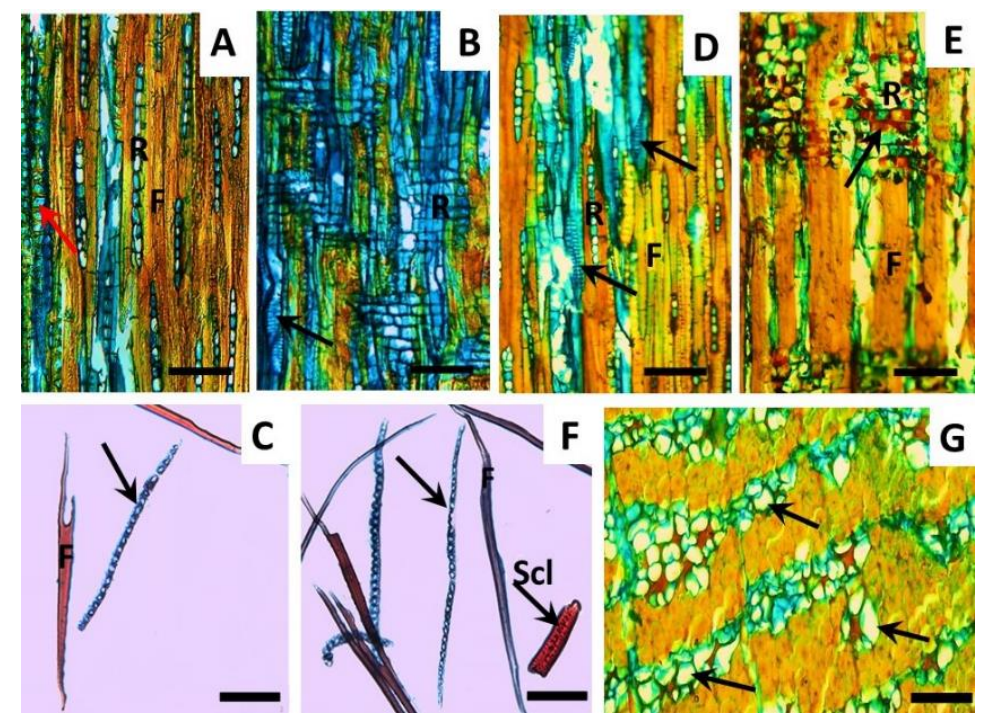

Fig. 4 Secondary phloem of (A to C) Tachigali guianensis and (D to $G$ ) Tachigali glauca: (A) crystals in chambered axial parenchyma cells (arrow) and uniseriate rays (R) and fibers (F) (tangential section); (B) homocellular rays $(R)$ and sieve tube elements with compound sieve plates (black arrow) (radial section); (D) sieve tube elements with compound sieve plates (black arrows), fibers $(F)$, and uniseriate rays $(R)$ (tangential section); $(E)$ rays with phenolic compounds (arrow) and fibers (F) (radial section); ( $\mathrm{C}$ and F) crystals in thin-walled septate crystal strands (arrow), fibers (F), and sclerified cell (Scl) (maceration); and (G) secretory cells (arrow), some of which with brown contents (transverse section). Scale bars: (A, B, D, and E) $40 \mu \mathrm{m}$, (C and F) $100 \mu \mathrm{m}$, and (G) $20 \mu \mathrm{m}$

The fibers represented $30.5 \%$ and $34.5 \%$ of the secondary phloem tissues in $T$. guianensis and $T$. glauca, respectively. They were slender with tapered overlapping ends, although they were sometimes bifurcated (Fig. 4C). The fibers had average lengths of 1040 $\mu \mathrm{m} \pm 107 \mu \mathrm{m}$ and $970 \mu \mathrm{m} \pm 91 \mu \mathrm{m}$, diameters of $24 \mu \mathrm{m} \pm 2 \mu \mathrm{m}$ and $25 \mu \mathrm{m} \pm 0.3 \mu \mathrm{m}$, and wall thicknesses of $12 \mu \mathrm{m} \pm 0.1 \mu \mathrm{m}$ and $10 \mu \mathrm{m} \pm 0.6 \mu \mathrm{m}$ in $T$. guianensis and T. glauca, respectively. Fibers were rounded to polygonal in T. guianensis and square in T. glauca in the transverse sections (Figs. 2F, 3D, and 3E) and composed the ground tissue. In both species, fibers were accompanied by crystals, presumably of calcium oxalate, in chambered parenchyma cells (Fig. 4A, 4C, and 4F). The abundant crystals provide mechanical support to the barks and defense against herbivores, and they are also found in other species of Leguminosae, such as Albizia julibrissin (Furuno 1990), Sclerolobium aureum, S. paniculatum var. rubiginosum, S. paniculatum var. subvelutinum, Acacia polyphylla, Copaifera langsdorffii, Mimosa laticifera (Costa et al. 1997), Schizolobium parahyba 
(Marcati et al. 2008), Albizia niopoides (Carmo et al. 2016a), Anadenanthera peregrina, and A. colubrina (Mota et al. 2017).

The sclerenchyma also contained sclereids, which were present in groups in the nonconducting phloem and cortex, mainly near the periderm (Figs. 2C, 3C, and 4F), representing $15.5 \%$ in $T$. guianensis and $9.0 \%$ in $T$. glauca. Sclereids were generally isodiametric, with average diameters of $62.1 \mu \mathrm{m} \pm 11.6 \mu \mathrm{m}$ and $56.9 \mu \mathrm{m} \pm 6.9 \mu \mathrm{m}$, respectively, with variable shapes and sizes with thick and polylamellated walls. Sclereids often enclosed one or two prismatic crystals and also phenolic compounds (Fig. 2C). Sclereids are recorded for many species of Sclerolobium, such as S. aureum, S. paniculatum var. rubiginosum, and S. Paniculatum var. subvelutinum (Costa et al. 1997).

Secretory cells were observed in the nonconducting tissue in small tangential groups (Figs. 2D, 2F, 3D, and 4G), giving a conspicuous pattern to the bark. A conspicuous feature of these barks was the presence of extensive phenolic deposits in, for example, tanniferous cells, especially in the rhytidome and in the nonconducting phloem (Figs. 2, $3 \mathrm{~A}$ to $3 \mathrm{D}, 4 \mathrm{E}$, and $4 \mathrm{G})$.

\section{Chemical Composition}

Table 1 summarizes the chemical compositions of the barks of the two studied species of the genus Tachigali: T. guianensis and T. glauca. There have been no studies on these barks, so comparisons were made with barks of other species.

Table 1. Average Chemical Compositions (\% of total o.d. mass) of Tachigali guianensis and Tachigali glauca

\begin{tabular}{|c|c|c|}
\hline Compound & T. guianensis (wt\%) & T. glauca (wt\%) \\
\hline Ash & 3.5 & 4.5 \\
\hline Extractives, total & 18.0 & 15.3 \\
\hline Dichloromethane & 1.5 & 1.1 \\
\hline Ethanol & 9.5 & 9.6 \\
\hline Water & 7.0 & 4.6 \\
\hline Suberin & 1.8 & 1.0 \\
\hline Klason lignin & 25.5 & 26.1 \\
\hline Soluble lignin & 1.3 & 1.7 \\
\hline Lignin, total & 26.8 & 27.8 \\
\hline Polysaccharides & 38.4 & 38.6 \\
\hline${ }^{*}$ Determined by difference & & \\
\hline
\end{tabular}

The contents of extractives were high and similar for both species: $18.0 \%$ and $15.3 \%$, respectively, for $T$. guianensis and $T$. glauca barks. The main contribution came from polar compounds solubilized by ethanol and water, representing $91.5 \%$ and $93.0 \%$, respectively, of the total extractives for $T$. guianensis and $T$. glauca barks. The high extractives contents and substantial polar fraction is in line with the anatomical observations of phenolic deposits in the cells (Fig. 2B and 2C). This result also aligns with barks of other tropical species, such as Albizia niopoides (14.5\% total extractives and $12.2 \%$ polar extractives) (Carmo et al. 2016a), Copaifera langsdorffii (21.3\% and 19.2\%) (Carmo et al. 2016b), Goupia glabra (22.5\% and 21.8\%) (Carmo et al. 2016c), Tectona grandis $(10.7 \%$ and 9.0\%) (Baptista et al. 2013), E. urophylla $\times$ E. grandis and $E$. 
urophylla $\times$ E. camaldulensis (14.3\% to $17.6 \%$, and $12.0 \%$ to $16 \%$ ) (Sartori et al. 2016), Quercus laurina (19.3\% with $12.7 \%$ ethanol solubles) and Quercus crassifolia (outer bark) (12.7\% with $4.3 \%$ ethanol extract) (Ruiz-Aquino et al. 2015), and Anadenanthera peregrina and Anadenanthera colubrina (28.8\% and $28.9 \%$ with $25.7 \%$ and $26.6 \%$ polar extractives) (Mota et al. 2017). Waxes and other non-polar compounds that are soluble in dichloromethane composed the remaining bark extractives, representing only approximately $8.1 \%$ of the total extractives in T. guianensis bark and $7.0 \%$ in $T$. glauca bark.

The T. guianensis and T. glauca barks were low in suberin (less than $2 \%$ ), which is consistent with the small proportion of phellem cells found in the rhytidome in both species and their being thin-walled. Suberin is the chemical fingerprint of phellem (cork) cells and is not a component of other cell types. Therefore, only barks with a substantial proportion of cork have a high content of suberin, e.g., Quercus cerris (28.5\%) (Şen et al. 2010), Betula pendula (5.9\%) (Miranda et al. 2013), Q. laurina (26.6\%) and Q. crassifolia (20.1\%) (Ruiz-Aquino et al. 2015), and Pseudotsuga menziesii (26.8\%) (Ferreira et al. 2015). In barks with little development of cork, the suberin content is therefore low, as in Tectona grandis (1.9\%) (Baptista et al. 2013), A. niopoides (0.8\%) (Carmo et al. 2016a), G. glabra (1.1\%) (Carmo et al. 2016c), A. peregrina and A. colubrina (2.4\% and $2.6 \%$ ) (Mota et al. 2017), and Eucalyptus species (Miranda et al. 2013)

The T. guianensis and T. glauca barks showed similar degrees of lignification (27\% and $28 \%$, respectively). They had lower lignin contents in comparison to other barks from tropical species such as A. niopoides (37.1\%) (Carmo et al. 2016a), G. glabra (43.8\%) (Carmo et al. 2016c), Q. laurina and Q. crassifolia (36.9\% and 39.6\%) (Ruiz-Aquino et al. 2015), but were similar to barks of $A$. peregrina and A. colubrina (18.8\% and $18.9 \%$ ) (Mota et al. 2017) and of six Eucalyptus urophylla hybrids (18.1\% to 21.2\%) (Sartori et al. 2016)

The contents and compositions of polysaccharides of the barks of both species were similar (38.4\% and 38.6\% of the bark, respectively, for T. guianensis and T. glauca) (Table $2)$. Cellulose, as estimated from the glucan content, was the major component $(72.8 \%$ and $84.4 \%$, respectively, of the total neutral monomeric sugars in the $T$. guianensis and $T$. glauca barks). Hemicelluloses included mostly xylose $(17.9 \%$ and $11.6 \%$ of the total neutral monomeric sugars, respectively).

Table 2. Average Carbohydrate Compositions of Barks from Tachigali guianensis and Tachigali glauca, in \% of Total Monosaccharides

\begin{tabular}{|c|c|c|}
\hline Monosaccharide Composition & $\begin{array}{c}\text { T. guianensis }(\% \text { of } \\
\text { total neutral sugars) }\end{array}$ & $\begin{array}{c}\text { T. glauca (\% of total } \\
\text { neutral sugars) }\end{array}$ \\
\hline Rhamnose & 0.5 & 0.2 \\
\hline Arabinose & 3.9 & 1.9 \\
\hline Xylose & 17.9 & 11.6 \\
\hline Mannose & 2.4 & 1.5 \\
\hline Galactose & 2.5 & 2.1 \\
\hline Glucose & 72.8 & 82.8 \\
\hline
\end{tabular}

The monomeric compositions of polysaccharides were consistent with published results for other eucalypt barks in relation to the predominance of glucose and a substantial xylose content, although the individual compositions vary with species. Mota et al. (2017), 
for A. peregrina and A. colubrina barks, obtained analogous results, with a predominance of glucose $(82.9 \%$ and $81.2 \%$ of total neutral monosaccharides), followed by xylose $(8.7 \%$ and $8.9 \%$ ). Carmo et al. (2016b) reported, for C. langsdorffii bark, glucose being $66.4 \%$ of total monosaccharides and xylose being $18.9 \%$. In E. urophylla hybrids' barks, glucose represented $84.4 \%$ of total neutral monosaccharides, and xylose represented $9.5 \%$ (Sartori et al. 2016).

Ash contents were 3.5\% (T. guianensis) and 4.5\% (T. glauca). Literature data are similar, e.g., 3.7\% for Copaifera langsdorffii (Carmo et al. 2016b) and 3\% for E. globulus (Miranda et al. 2013).

\section{Ethanol-water Extracts}

The ethanol-water extraction yields and the results for total phenolic, total flavonoid, and tannin contents in the studied extracts are shown in Table 3. The extraction yields obtained with ethanol/water (13.8\% for T. guianensis and $10.8 \%$ for T. glauca) were lower than the sums of the sequential solvent extraction yields with ethanol and water (16.5\% for T. guianensis and $14.2 \%$ for $T$. glauca, Table 1). These differences can be explained by the mild extraction conditions applied (temperature and duration of extraction).

Table 3. Extraction Yields, Total Phenolic Contents, Tannin and Flavonoid Contents, and Antioxidant Activities of Tachigali guianensis and Tachigali glauca

\begin{tabular}{|c|c|c|}
\hline & T. guianensis & T. glauca \\
\hline Extraction yield $(\%)$ & 13.8 & 10.8 \\
\hline Total phenolic content (mg GAE / g of dry extract) & 441.1 & 641.7 \\
\hline Flavonoids $(\mathrm{mg}$ catechin / g of dry extract) & 69.5 & 373 \\
\hline Tannins (mg catechin / g of dry extract) & 190.0 & 427.5 \\
\hline Antioxidant capacity $(\mathrm{mg}$ Trolox / g of dry extract) & 440.3 & 585.3 \\
\hline Antioxidant capacity $(\mathrm{mg}$ Trolox / g of dry bark) & 60.9 & 63.1 \\
\hline$I C_{50}(\mu \mathrm{g}$ extract / $\mathrm{mL})$ & 7.3 & 5.6 \\
\hline$I C_{50}$ (Trolox in ethanol-water) $(\mu \mathrm{g}$ Trolox / $\mathrm{mL})$ & \multicolumn{2}{|c|}{5.39} \\
\hline$I C_{50}$ (catechin in ethanol-water) $(\mu \mathrm{g}$ catechin $/ \mathrm{mL})$ & \multicolumn{2}{|c}{} \\
\hline
\end{tabular}

The concentration of total phenolics was greater in the $T$. glauca bark extract than in the T. guianensis bark extract (respectively, $641.7 \mathrm{mg}$ GAE / $\mathrm{g}$ of extract and $441.1 \mathrm{mg}$ GAE / $g$ of extract). These values are particularly high when compared to barks from other tropical species such as A. niopoides (247.15 mg GAE / g of extract) (Carmo et al. 2016a) or G. glabra (158.2 mg GAE / g of extract) (Carmo et al. 2016c). Comparison with barks of other hardwood species shows a similar range of values, e.g., ethanol-water extracts of barks of six Eucalyptus urophylla hybrids from Brazil (210.9 mg GAE / g of extract to $550.9 \mathrm{mg} \mathrm{GAE} / \mathrm{g}$ of extract) (Sartori et al. 2016) and C. langsdorffii from the Amazon (589.2 mg GAE / g of extract) (Carmo et al. 2016b).

The flavonoid content was high, especially for the $T$. glauca bark extract $(373.0 \mathrm{mg}$ CE / g of extract, vs. $69.5 \mathrm{mg} \mathrm{CE} \mathrm{/} \mathrm{g} \mathrm{of} \mathrm{extract} \mathrm{for} \mathrm{the} \mathrm{T.} \mathrm{guianensis} \mathrm{bark} \mathrm{extract),} \mathrm{which}$ also contained substantially more tannins (427.5 mg CE / g of extract $v s .190 \mathrm{mg} \mathrm{CE} / \mathrm{g}$ of extract for the $T$. guianensis bark extract). A large range of values of flavonoid content have been reported for other hardwood barks, such as Copaifera langsdorffii (442 mg CE 
/ g of extract) (Carmo et al. 2016b), A. niopoides (59.08 $\mathrm{mg}$ CE / g of extract in ethanol/water) (Carmo et al. 2016a), the six Eucalyptus urophylla hybrids from Brazil (flavonoids from $98.0 \mathrm{mg} \mathrm{CE} / \mathrm{g}$ of extract to $234.5 \mathrm{mg} \mathrm{CE} / \mathrm{g}$ of extract), and Anadenanthera peregrina and A. colubrina (148.4 mg CE / g of extract and $445.3 \mathrm{mg} \mathrm{CE}$ / g of extract, respectively) (Mota et al. 2017).

The contents of condensed tannins for both Tachigali species were higher than those reported for ethanol/water extracts of barks of A. peregrina (586.9 mg CE / $\mathrm{g}$ of extract) and A. colubrina (97.5 mg CE / g of extract) (Mota et al. 2017), E. urophylla hybrids (76 mg CE / g of extract to $184 \mathrm{mg} \mathrm{CE} \mathrm{/} \mathrm{g} \mathrm{of} \mathrm{extract)} \mathrm{(Sartori} \mathrm{et} \mathrm{al.} \mathrm{2016),} \mathrm{C.}$ langsdorffii (54.8 mg CE / g of extract) (Carmo et al. 2016b), and E. globulus (125 mg CE / g of extract) (Neiva et al. 2018a).

The radical scavenging activities displayed by the bark extracts corresponded to IC 50 values of $7.3 \mu \mathrm{g}$ extract $/ \mathrm{mL}$ and $5.6 \mu \mathrm{g}$ extract $/ \mathrm{mL}$, respectively, for T. guianensis and $T$. glauca. These values compare favorably with the $I_{50}$ values of well-known antioxidant standards such as catechin $(5.39 \mu \mathrm{g} / \mathrm{mL})$ and Trolox $(1.58 \mu \mathrm{g} / \mathrm{mL})$.

The obtained results show that these bark extracts have the potential to be used as additives in food, drugs, and other industrial products taking advantage of their antioxidant properties. A valorization route for both Tachigali species may therefore consider the bark separation at tree harvest and the extraction of polar compounds followed by their fractionation and purification. Studies on optimization of extraction methods as well as investigation of further biological activities of bark extracts should therefore be undertaken.

\section{CONCLUSIONS}

1. Tachigali guianensis and T. glauca barks were characterized for the first time regarding anatomical structure and chemical composition.

2. The barks of both species were similar in external aspects and anatomical features, such as a poorly developed rhytidome with one to two periderms, frequent lenticels, a continuous ring of sclerified cells below the periderm, a widely dilated and sclerified nonconducting phloem, the presence of septate crystal strands, and extensive phenolic deposits in cells. Differences between the two species mainly concerned development and arrangement of sclerenchyma.

3. The striking chemical feature of $T$. guianensis and $T$. glauca barks is the high content of extractives, especially of polar extractives that are rich in phenolic compounds, namely flavonoids and tannins, with good antioxidant activities. Both barks also contained high amounts of carbohydrates, specifically cellulose.

4. The T. guianensis and T. glauca barks showed promising results as sources for phenolic compounds and potential use as antioxidants.

\section{ACKNOWLEDGMENTS}

Graciene da Silva Mota and Caroline Junqueira Sartori were supported by Individual PhD Sandwich Scholarships of CAPES (Coordenação de Apoio ao Pessoal de 
Nivel Superior, Brazil), and this work was financially supported by FAPEMIG (Fundação de Apoio a Pesquisa do Estado de Minas Gerais, Brazil) and CNPq (Con-selho Nacional de Pesquisa Científica, Brazil). This work is part of the research activities of Centro de Estudos Florestais (CEF), a research unit supported by FCT - Fundação para a Ciência e a Tecnologia of Portugal (UID/00239/2013/2020). The authors thank Joaquina Silva for help with the chemical analysis and Cristiana Alves for help with the anatomical work.

Funding: The Open Access was funded by CEF Project UIDB/00239/2020

\section{REFERENCES CITED}

Abdalla, S., Pizzi, A., Ayed, N., Charrier-El Bouthoury, F., Charrier, B., Bahabri, F., and Ganash, A. (2014). "MALDI-TOF analysis of Aleppo pine (Pinus halepensis) bark tannin,” BioResources 9(2), 3396-3406. DOI: 10.15376/biores.9.2.3396-3406

Alonso, A. A., and Machado, S. R. (2008). "Stem protective tissue in Erythroxylum tortuosum (Erythroxylaceae), a fire tolerant species from cerrado,” IAWA J. 29(1), 69-77. DOI: 10.1163/22941932-90000171

Angyalossy, V., Pace, M. R., Evert, R. F., Marcati, C. R., Oskolski, A. A., Terrazas, T., Kotina, E., Lens, F., Mazzoni-Viveiros, S. C., Angeles, G., et al. (2016). "IAWA list of microscopic bark features," IAWA J. 37(4), 517-615. DOI: 10.1163/2294193220160151.

Aparecido, L. M. T., Santos, J. D., Higuchi, N., and Kunert, N. (2019). "Relevance of wood anatomy and size of Amazonian trees in the determination and allometry of sapwood area," Acta Amaz. 49(1), 1-10. DOI: 10.1590/1809-4392201800961

Araujo, E. d. S., Mota, G. d. S., Lorenço, M. S., Zidanes, U. L., da Silva, L. R., Silva, E. P., Ferreira, V. R. F., Cardoso, M. d. G., and Mori, F. A. (2020). "Characterisation and valorisation of the bark of Myrcia eximia DC. trees from the Amazon rainforest as a source of phenolic compounds," Holzforschung DOI: 10.1515/hf-2019-0294

Baptista, I., Miranda, I., Quilhó, T., Gominho, J., and Pereira H. (2013). "Characterisation and fractioning of Tectona grandis bark in view of its valorisation as a biorefinery raw-material," Ind. Crop. Prod. 50, 166-175. DOI: 10.1016/j.indcrop.2013.07.004

Barbosa, A. C. F., Pace, M. R., Witovisk, L., and Angyalossy, V. (2010). "A new method to obtain good anatomical slides of heterogeneous plant parts," IAWA J. 31(4), 373383. DOI: 10.1163/22941932-90000030

Camargos, J. A. A., Coradin, V. T. R., Czarneski, C. M., Oliveira, D. d., and Meguerditchian, I. (2001). Catálogo de Árvores do Brasil, IBAMA, Brasília, Brazil.

Cardoso, S., Ferreira, J., Miranda, I., and Pereira, H. (2018). "Age variation of Douglasfir bark chemical composition," J. Wood Chem. Technol. 38(5), 385-396. DOI: 10.1080/02773813.2018.1513036

Carmo, J. F., Miranda, I., Quilhó, T., Sousa, V. B., Carmo, F. H. D. J., Latorraca, J. V. F., and Pereira, H. (2016a). "Chemical and structural characterization of the bark of Albizia niopoides trees from the Amazon," Wood Sci. Technol. 50, 677-692. DOI: 10.1007/s00226-016-0807-3

Carmo, J. F., Miranda, I., Quilhó, T., Sousa, V. B., Cardoso, S., Carvalho, A. M., Carmo, F. H. D. J., Latorraca, J. V. F., and Pereira, H. (2016b). "Copaifera langsdorffii bark as a source of chemicals: Structural and chemical characterization," J. Wood Chem. 
Technol. 36(5), 305-317. DOI: 10.1080/02773813.2016.1140208

Carmo, J. F., Miranda, I., Quilhó, T., Carvalho, A. M., Carmo, F. H. D. J., Latorraca, J. V. F., and Pereira. H. (2016c). "Bark characterisation of the Brazilian hardwood Goupia glabra in terms of its valorization," BioResources 11(2), 4794-4807. DOI: 10.15376/biores.11.2.4794-4807

Costa, C. G., Coradin, V. T. R., Czarneski, C. M., and Pereira, B. A. d. S. (1997). "Bark anatomy of arborescent Leguminosae of cerrado and gallery forest of central Brazil," IAWA J. 18(4), 385-399. DOI: 10.1163/22941932-90001504

do Vale, A. T., Dias, Í. S., and Santana, M. A. E. (2010). "Relationships among chemical properties, physical and energy wood properties of five cerrado species," Ciênc. Florest. 20(1), 137-145. DOI: 10.5902/198050981767

dos Santos Silva, M. O., da Silva, M. G., Bufalino, L., de Assis, M. R., de Almeida Gonçalves, D., Trugilho, P. F., and de Paula Protásio, T. (2019). "Variations in productivity and wood properties of Amazonian tachi-branco trees planted at different spacings for bioenergy purposes,"J. Forestry. Res. DOI:10.1007/s11676-019-01068-8

Fedalto, L. C., Mendes, I. d. C. A., and Coradin, V. T. R. (1989). Madeiras da Amazônia: Descrição do Lenho de 40 Espécies Ocorrentes na Floresta Nacional do Tapajós, IBAMA, Brasília, Brazil.

Ferreira, J. P. A., Miranda, I., Gominho, J., and Pereira, H. (2015). "Selective fractioning of Pseudotsuga menziesii bark and chemical characterization in view of an integrated valorization," Ind. Crop. Prod. 74, 998-1007. DOI: 10.1016/j.indcrop.2015.05.065

Ferreira, J. P. A., Quilhó, T., and Pereira, H. (2017). "Characterization of Betula pendula outer bark regarding cork and phloem components at chemical and structural levels in view of biorefinery integration," J. Wood Chem. Technol. 37(1), 10-25. DOI: 10.1080/02773813.2016.1224248

Ferreira, J. P. A., Miranda, I., and Pereira, H. (2018). "Chemical composition of lipophilic extractives from six Eucalyptus barks," Wood Sci. Technol. 52, 1685-1699. DOI: $10.1007 / \mathrm{s} 00226-018-1054-6$

Furuno, T. (1990). "Bark structure of deciduous broad-leaved trees grown in the San'in region, Japan” IAWA J. 11(3), 239-254. DOI: 10.1163/22941932-90001181

Gama, J. R. V., Botelho, S. A., and Bentes-Gama, M. d. M. (2002). "Floristic composition and natural regeneration of a secondary low floodplain forest in the Amazonian estuary," Rev. Árvore, 26(5), 559-566. DOI: 10.1590/S010067622002000500005

Gasson, P., Trafford, C., and Matthews, B. (2003). "Wood anatomy of Caesalpinioideae," in: Advances in Legume Systematics, Part 10: Higher Level Systematics, B. B.

Klitgaard and A. Bruneau (eds.), Royal Bot. Gardens, Kew, London, UK, pp. 63-93.

Gominho, J., Costa, R. A., Lourenço, A., Quilhó, T., and Pereira, H. (2020). "Eucalyptus globulus stumps bark: Chemical and anatomical characterization under a valorisation perspective," Waste Biomass Valori. DOI: 10.1007/s12649-020-01098-y

Graham, A., and Barker, G. (1981). "Palynology and tribal classification in the Caesalpinioideae, ” in: Advances in Legume Systematics, Part 2, R. M. Polhill and P. H. Raven (eds.), Royal Botanic Gardens, Kew, London, UK, pp. 801-834.

Harkin, J. M., and Rowe, J. W. (1971). Bark and Its Possible Uses (Research Note FPL091), U. S. Department of Agriculture, Forest Products Lab., Madison, WI, USA.

Haston, E. M., Lewis, G. P., and Hawkins, J. A. (2005). “A phylogenetic reappraisal of the Peltophorum group (Caesalpinieae: Leguminosae) based on the chloroplast trnLF, rbcL and rps16 sequence data," Am. J. Bot. 92(8), 1359-1371. DOI: 
10.3732/ajb.92.8.1359

Huamantupa-Chuquimaco, I., Lima, H. C., Cardoso, D., de la Vega, D. H., and LuzaVictorio, M. A. (2016). "Taxonomic, ecological and ethnobotanical synopsis of the genus Tachigali Aubl. (Leguminosae) in the region of Cusco, Peru,". Rev. Q'EUÑA 7, 7-30.

Jansone, Z., Muizniece, I., and Blumberga, D. (2017). "Analysis of wood bark use opportunities," Energy Procedia 128, 268-274. DOI: 10.1016/j.egypro.2017.09.070

Leite, C., and Pereira, H. (2017). "Cork-containing barks-A review," Front. Mater. 3. DOI: $10.3389 /$ fmats.2016.00063

Lewis, G. P., Schrire, B., Mackinder, B., and Lock, M. (2005). Legumes of the World. Royal Botanical Gardens, Kew, London, UK.

Lima, L., Miranda, I., Knapic, S., Quilhó, T., and Pereira, H. (2018). "Chemical and anatomical characterization, and antioxidant properties of barks from 11 Eucalyptus species," Eur. J. Wood Wood Prod. 76(2), 783-792. DOI:10.1007/s00107-017-1247-y

Lorenzi, H. (1992). Árvores Brasileiras: Manual de Identificação e Cultivo de Plantas Arbóreas Nativas do Brasil Vol. 1, H. Lorenzi (ed.), Plantarum, São Paulo, Brazil.

Lorenzi, H. (1998). Árvores Brasileiras: Manual de Identificação e Cultivo de Plantas Arbóreas Nativas do Brasil Vol 2. H. Lorenzi (ed.), Plantarum, São Paulo, Brazil.

Loureiro, A. A., Vasconcellos, F. J. d., and Freitas, J. A. d. (1983). "Contribution to the anatomical study of the wood of five species of Sclerolobium and five species of Tachigali (Leguminosae) from the Amazon," Acta Amaz. 13(1), 149-170. DOI: 10.1590/1809-43921983131149

Macedo, M. T., Barros, C. F., Lima, H. C., and Costa, G. C. (2014). "Wood anatomy of seven species of Tachigali (Caesalpinioideae-Leguminosae)," IAWA J. 35(1), 19-30. DOI: 10.1163/22941932-00000044

Marcati, C. R., Milanez, C. R. D., and Machado, S. R. (2008). "Seasonal development of secondary xylem and phloem in Schizolobium parahyba (Vell.) Blake (Leguminosae: Caesalpinioideae)," Trees 22(1), 3-12. DOI: 10.1007/s00468-007-0173-8

Ministry of the Environment (2019). "Biomes: Amazon," (http://www.mma.gov.br/biomas/amazônia), Accessed 7 September 2019.

Miranda, I., Gominho, J., and Pereira, H. (2012). "Incorporation of bark and tops in Eucalyptus globulus wood pulping," BioResources 7(3), 4350-4361.

Miranda, I., Gominho, J., Mirra, I., and Pereira, H. (2013). "Fractioning and chemical characterization of barks of Betula pendula and Eucalyptus globulus," Ind. Crop. Prod. 41, 299-305. DOI: 10.1016/j.indcrop.2012.04.024

Mota, G. S., Sartori, C. J., Miranda, I., Quilhó, T., Mori, F. A. and Pereira, H. (2017). "Bark anatomy, chemical composition and ethanol-water extract composition of Anadenanthera peregrina and Anadenanthera colubrina," PLOS ONE 12. DOI: 10.1371/journal.pone.0189263

Neiva, D. M., Gominho, J., Fernandes, L., Lourenço, A., Chemetova, C., Simões, R. M. S., and Pereira, H. (2016). "The potential of hydrothermally pretreated industrial barks from E. globulus as a feedstock for pulp production," J. Wood Chem. Technol. 36(6), 383-392. DOI: 10.1080/02773813.2016.1184280

Neiva, D. M., Araújo, S., Gominho, J., Carneiro, A. d. C., and Pereira, H. (2018a). "Potential of Eucalyptus globulus industrial bark as a biorefinery feedstock: Chemical and fuel characterization," Ind. Crop. Prod. 123, 262-270. DOI:

10.1016/j.indcrop.2018.06.070

Neiva, D. M., Araújo, S., Gominho, J., Carneiro, A. d. C., and Pereira, H. (2018b). “An 
integrated characterization of Picea abies industrial bark regarding chemical composition, thermal properties and polar extracts activity," PLoS ONE 13(11). DOI: 10.1371/journal.pone.0208270

Orellana, B. B. M. A., do Vale, A. T., Gonçalez, J., Guedes, M. C., Orellana, J. B. P., and Lima, C. M. (2018). "Energetic density of Tachigali vulgaris wood by diametric class in two experimental plants in the Amazon," Nativa Sinop 6, 773-781. DOI: 10.31413/nativa.v6i0.5130

Ortiz, J., Hernández, L., and Worbes, M. (2006). "Radial growth of Tachigali and Terminalia in lowland forests in Southeast Venezuela," Acta Bot. Venez. 29(2), 211234.

Pereira, B. A. d. S. (1990). Morpho-anatomical study of wood, bark and leaf of two vicarious varieties of Sclerolobium paniculatum Vogel (Leguminosae, Caesalpinioideae) from forest and cerrado, Master's Thesis, University of São Paulo, São Paulo, Brazil. DOI: 10.11606/D.11.2019.tde-20191218-112750

Pereira, H. (1988). "Chemical compositions and variability of cork from Quercus suber L.,"Wood Sci. Technol. 22, 211- 218. DOI: 10.1007/BF00386015

Pereira, H. (2007). Cork: Biology, Production and Uses, Elsevier Publications, Amsterdam, Netherlands.

Pernía, N. E. d., and Melandri, J. L. (2006). "Wood anatomy of the tribe Caesalpinieae (Leguminosae, Caesalpinioideae) in Venezuela," IAWA J. 27(1), 99-114. DOI: 10.1163/22941932-90000140

Quilhó, T., Sousa, V., Tavares, F., and Pereira, H. (2013). "Bark anatomy and cell size variation in Quercus faginea," Turk. J. Bot. 37, 561-570. DOI: 10.3906/bot-1201-54

Reis, A. R. S., Reis, P. C. M. d., Brandão, A. T. d. O., and Lisboa, P. L. B. (2011). "The anatomy of the secondary xylem of seven species of the Tachigali Aubl. type. from the Walter A. Egler wood collection of the Museu Paraense Emílio Goeldi, Pará, Brazil," Bol. Mus. Para. Emilio Goeldi Cienc. Nat. 6(3), 319-333.

Reis, A. d. S., Sousa, J. d. S. d., Bastos, M. d. N. d. C., and Sobral, S. F. (2015). "Taxonomy of Tachigali Aubl. (Leguminosae, Caesalpinioideae) the metropolitan region of Belém, Pará, Brasil," Biota Amazôn. 5(4), 48-55. DOI: 10.18561/21795746/biotaamazonia.v5n4p48-55

Roth, I. (1981). "Structural patterns of tropical barks," in: Encyclopedia of Plant Anatomy Vol. IX, Part 3, Borntraeger, Berlin, Germany.

Ruiz-Aquino, F., González-Peña, M. M., Valdez-Hernández, J. I., Revilla, U. S., and Romero-Manzanares, A. (2015). "Chemical characterization and fuel properties of wood and bark of two oaks from Oaxaca, Mexico," Ind. Crop. Prod. 65, 90-95. DOI: 10.1016/j.indcrop.2014.11.024

Sartori, C., da Silva Mota, G., Ferreira, J., Miranda, I., Mori, F. A., and Pereira, H. (2016). "Chemical characterization of the bark of Eucalyptus urophylla hybrids in view of their valorization in biorefineries," Holzforschung 70(9), 819-828. DOI: 10.1515/hf-2015-0258

Şen, A., Miranda, I., Santos, S., Graça, J., and Pereira, H. (2010). “The chemical composition of cork and phloem in the rhytidome of Quercus cerris bark," Ind. Crop. Prod. 31(2), 417-422. DOI: 10.1016/j.indcrop.2010.01.002

Şen, A., Quilhó, T., and Pereira, H. (2011). "Bark anatomy of Quercus cerris L. var. cerris from Turkey," Turk. J. Bot. 35(1), 45-55. DOI: 10.3906/bot-1002-33

Sharma, O. P., and Bhat, T. K. (2009). "DPPH antioxidant assay revisited," Food Chem. 113(4), 1202-1205. DOI: 10.1016/j.foodchem.2008.08.008 
Silva, C. V. M. d. (2018). Cronossequência de Deterioração na Anatomia de Madeiras Tropicais Estocadas em Área de Mineração, Master's Thesis, Federal Rural University of the Amazon, Belém, Brazil.

Silva, L. F. G. d., and de Lima, H. C. (2007). "Nomenclatural changes in the genus Tachigali Aubl. (Leguminosae - Caesalpinioideae) in Brazil," Rodriguésia 58(2), 397-401. DOI: 10.1590/2175-7860200758214

Singleton, V. L., and Rossi, J. A. (1965). "Colorimetry of total phenolics with phosphomolybdic-phosphotungstic acid reagents," Am. J. Enol. Viticult. 16, 144-158.

Soares, A. A., Neves, R. L., Schwartz, G., Emmert, F., and Nascimento, R. G. M. (2019). "Performance of Tachigali glauca Tul. under different treatments in eastern Amazon gaps," in: $4^{\circ}$ Congreso Latinoamer. Estructuras de Maderas, Montevideo, Uruguay.

Soratto, D. N., Cunha, A. B. d., Vital, B. R., Carneiro, A. d. C. O., and Costa, F. R. (2013). "Effects of the addition of chips with barks on the quality of MDP panels produced with Eucalyptus sp.," Braz. J. Wood Sci. 4(1), 46-59. DOI: 10.12953/21776830.v04n01a04

Tanase, C., Cosarca, S., Muntean, D.-L. (2019). "A critical review of phenolic compounds extracted from the bark of woody vascular plants and their potential biological activity," Molecules 24, 1182. DOI: 10.3390/molecules24061182

TAPPI T211 om-02 (2002). "Ash in wood, pulp, paper and paperboard: combustion at $525^{\circ} \mathrm{C}$," TAPPI Press, Atlanta, GA, USA.

TAPPI T222 om-02 (2002). "Acid-insoluble lignin in wood and pulp," TAPPI Press, Atlanta, GA, USA.

TAPPI UM 250 om-93 (1993). “Acid-soluble lignin in wood and pulp,” TAPPI Press, Atlanta, GA, USA.

Tonini, H., Schwengber, D. R., Morales, M. M., and de Oliveira, J. M. F. (2018). "Growth and wood energy quality of Tachigali vulgaris in different spacing," Pesqui. Flor. Brasil. 38. DOI: 10.4336/2018.pfb.38e201801569

van der Werff, H. (2008). "A synopsis of the genus Tachigali (Leguminosae: Caesalpinioideae) in northern South America," Ann. Mo. Bot. Gard. 95(4), 618-661. DOI: $10.3417 / 2007159$

van der Werff, H., and Zamora V, N. A. (2010). "Notes on Tachigali (Leguminosae) in Central America with the description of a new species," Harv. Pap. Bot. 15(1), 149153.

Vázquez, G., Santos, J., Freire, M. S., Antorrena, G., and González-Álvarez, J. (2012). "Extraction of antioxidants from eucalyptus (Eucalyptus globulus) bark," Wood Sci. Technol. 46, 443-457. DOI: 10.1007/s00226-011-0418-y

Xu, Y., Xiao, H., Guan, H., and Long, C. (2018). "Monitoring atmospheric nitrogen pollution in Guiyang (SW China) by contrasting use of Cinnamomum Camphora leaves, branch bark and bark as biomonitors," Environ. Pollut. 233, 1037-1048. DOI: 10.1016/j.envpol.2017.10.005

Zhishen, J., Mengcheng, T., and Jinming, W. (1999). "The determination of flavonoid contents in mulberry and their scavenging effects on superoxide radicals," Food Chem. 64(4), 555-559. DOI: 10.1016/S0308-8146(98)00102-2

Article submitted: December 18, 2020; Peer review completed: February 7, 2021; Revised version received and accepted: February 17, 2021; Published: March 2, 2021. DOI: 10.15376/biores.16.2.2953-2970 